\title{
Cryptic Structural Differences at the Interstrain Level of Pisum sativum L.
}

\author{
Sumona Mukheriee and A. K. Sharma \\ Centre of Advanced Studies, (Cell and Chromosome Research), \\ Department of Botany, University of Calcutta, \\ 35, Ballygunge Circular Road, Calcutta-700 019, India
}

Accepted July 18, 1986

Pisum sativum L., the cultivated species of the family Leguminosae, includes a large number of strains with distinct and wide geographical distribution. The genus is one of the earliest genera in which controlled breeding work has been carried out for the production of improved types and it is the work on this genus that led to the foundation of the modern science of genetics. All the cultivated strains studied so far have $2 n=14$ chromosomes.

Notwithstanding the fact, that analysis of chromosomes of Pisum sativum has been studied earlier, no systematic analysis of the structure and behaviour of chromosomes of indigenous strains specially with a view to explore cryptic differences, if any, has been undertaken, excepting a few earlier records (Yarnell 1962, Sen and Tiwari 1966, Fauzdar and Tandem 1976, Sharma and Gupta 1982). In view of the vast potential of improved techiques of chromosome analysis, the present investigation was undertaken to analyse the minute structural differences of chromosomes at intraspecific level. The present study includes a detailed analysis of chromosome length and volume, chiasma frequency per cell and nucleus and classification of the finer details at the microscopic level.

\section{Materials and methods}

Seeds of eleven strains of Pisum sativum were obtained through the courtesy of different agricultural centres in India. The seeds were germinated at $25^{\circ} \mathrm{C}$, on moist filter paper, in petri-dishes and sown during the months of October and November in the Experimental Garden of the Department of Botany, University of Calcutta.

Somatic chromosomes were observed from root-tip cells. Young root-tips, cut into $2 \mathrm{~mm}$ segments, were pretreated in a saturated mixture of para-dichlorobenzene and aesculin at $12^{\circ} \mathrm{C}$ for $2 \mathrm{~h}$ followed by fixation in Newcomer's fluid for $1 \mathrm{~h}$. The root-tips were then slightly warmed and stained in 9:1 mixture of $2 \%$ propionic-orcein and $(\mathrm{N}) \mathrm{HCl}$.

Chromosome volume was measured using the formula:

$$
\mathrm{V}=\pi \mathrm{r}^{2} \mathrm{~h}
$$

where, $\mathrm{V}$ is the chromosome volume, $\mathrm{r}$ is the radius and $\mathrm{h}$ is the length of the chromosome.

Meiotic chromosomes were observed from pollen mother cells (PMCs). Flower buds were fixed in Newcomer's fluid for $1 \mathrm{~h}$ and the PMCs stained in $2 \%$ propionic-carmine along with a drop of ferric-acetate solution. All the stages of meiotic divisions, chiasma frequency and meiotic abnormalities were scanned from at least $100 \mathrm{PMCs}$ of each strain.

\section{Observations}

The chromosome complements revealed gross morphological similarities. The chromosomes were lcassified into 6 types according to the position of the centromeres and secondary 


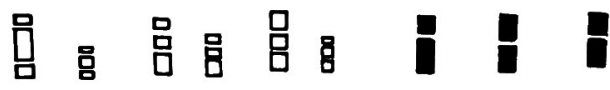 \\ A $B$ C $\quad$ D $E$ F}

\section{CHROMOSOME TYPES}

Fig. 1. Diagrammatic representation of chromosome types. constrictions (Fig. 1). Somatic chromosome number, $2 n=14$ is constant for all the strains (Figs. 2-12). The total chromosome length ranges from 53.4 to $70.8 \mu \mathrm{m}$ (Table 1). There are one to three pairs of chromosomes with secondary constrictions (Fig. 13). Total chromosome volume ranges within 38.9 to 89.9 cu. $\mu \mathrm{m}$ (Table 1). Total TF \% varies from 29.21 to $37.83 \%$ (Table 1). No somatic irregularities were noticed in any of the strains.

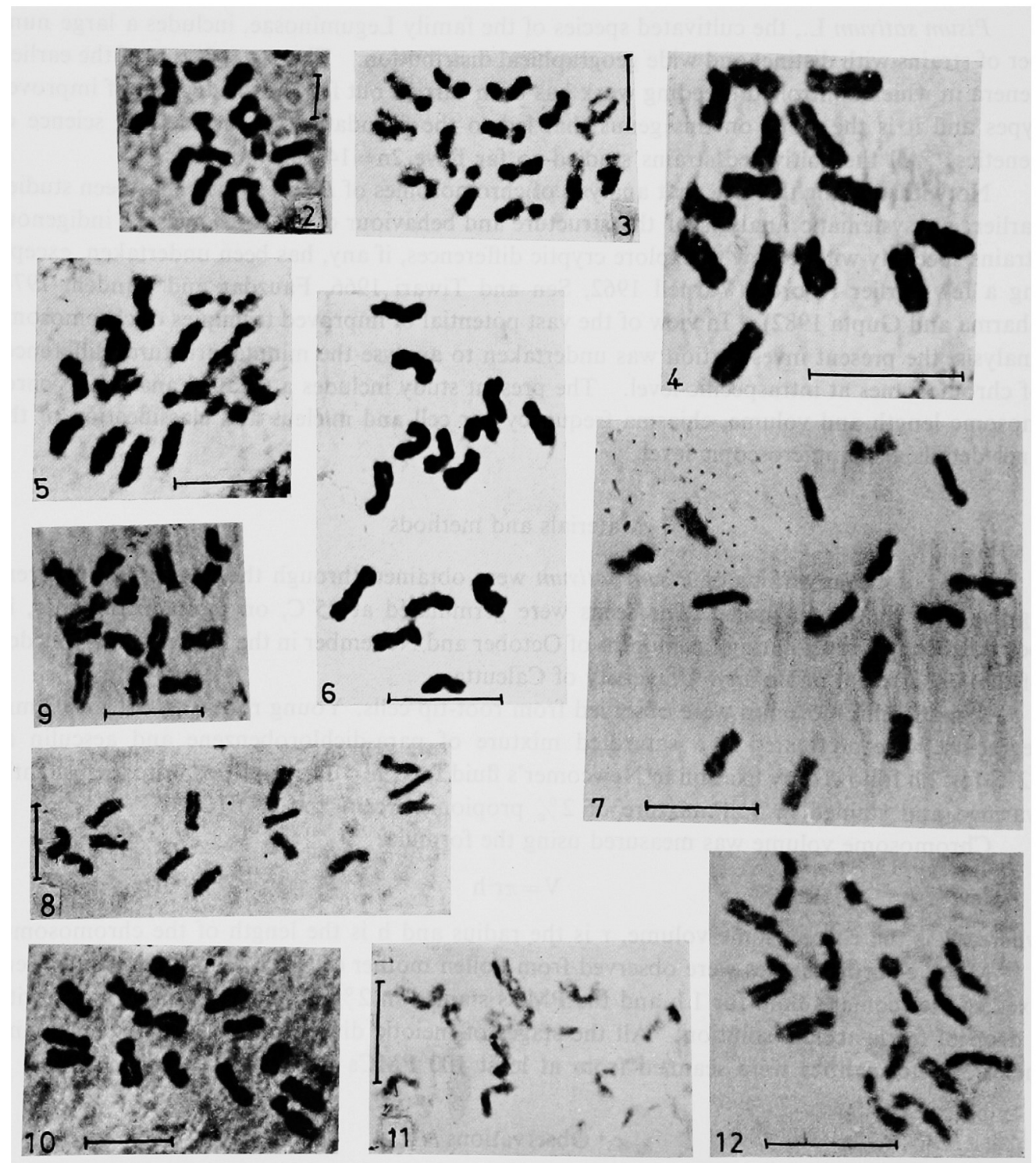

Figs. 2-12. Somatic metaphase plates of Pisum sativum L. showing $2 \mathrm{n}=14$ chromosomes. 2, PG-3. 3, T-163. 4, B22. 5, PLP-371. 6, EC-33866. 7, Bonneville. 8, PLP-401. 9, J-1. 10, Arkel. 11, PLP-525. 12, IC-775. $(\mathrm{Bar}=10 \mu \mathrm{m})$. 
Meiotic metaphase I manifested 7 regular bivalents (Figs. 14-24). Chiasma frequency per nucleus and per bivalent ranges from 7.84 to 12.9 and 1.1 to 1.8 respectively (Table 2). Despite regular behaviour of chromosomes, cytomixis was observed in the strains PLP-371 (Fig.

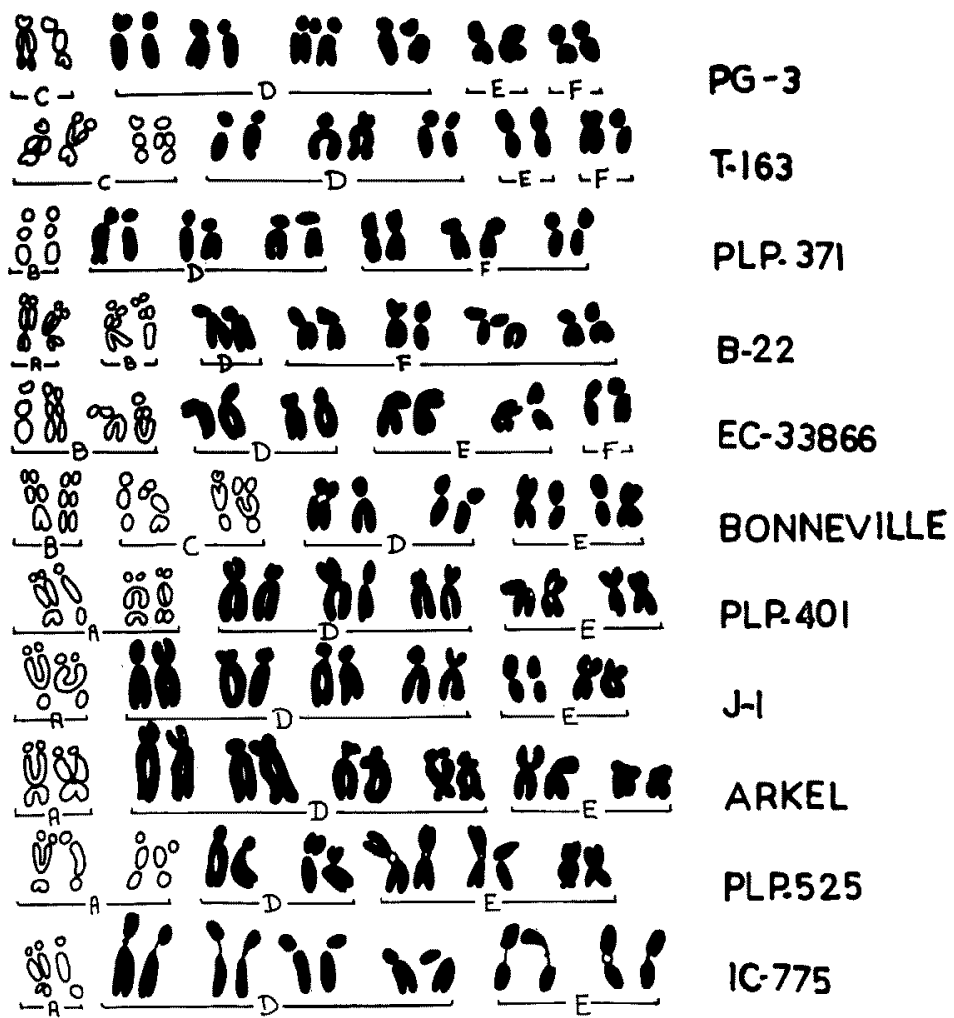

Karyograms of different strains of Pisum sotivum $L$.

Fig. 13. Comparative karyograms of the different strains in Pisum sativum L.

Table 1. Details of karyotype of eleven strains of Pisum sativum L.

$(2 n=14)$

\begin{tabular}{|c|c|c|c|c|c|c|c|}
\hline $\begin{array}{l}\text { Name } \\
\text { of the } \\
\text { strains }\end{array}$ & $\begin{array}{l}\text { Karyotype } \\
\text { formula }\end{array}$ & $\begin{array}{l}\text { Nos. of } \\
\text { chromo- } \\
\text { somes } \\
\text { with secon- } \\
\text { dary cons- } \\
\text { triction }\end{array}$ & TF $\%$ & $\begin{array}{l}\text { Range of } \\
\text { chromo- } \\
\text { some } \\
\text { length } \\
(\mu \mathrm{m})\end{array}$ & $\begin{array}{l}\text { Total } \\
\text { chromo- } \\
\text { some } \\
\text { length } \\
(\mu \mathrm{m})\end{array}$ & $\begin{array}{l}\text { Range of } \\
\text { chromo- } \\
\text { some } \\
\text { volume } \\
(\text { cu. } \mu \mathrm{m})\end{array}$ & $\begin{array}{c}\text { Total } \\
\text { chromo- } \\
\text { some } \\
\text { volume } \\
\text { (cu. } \mu \mathrm{m} \text { ) }\end{array}$ \\
\hline PG-3 & $\mathrm{C}_{2} \mathrm{D}_{8} \mathrm{E}_{2} \mathrm{~F}_{2}$ & 2 & 35.52 & $5.0-3.3$ & 55.4 & $7.1-4.5$ & 80.8 \\
\hline$T-163$ & $\mathrm{C}_{4} \mathrm{D}_{6} \mathrm{E}_{2} \mathrm{~F}_{2}$ & 4 & 33.81 & $4.5-3.6$ & 55.9 & $7.5-4.5$ & 89.9 \\
\hline B-22 & $\mathrm{A}_{2} \mathrm{~B}_{2} \mathrm{E}_{10}$ & 4 & 36.19 & $4.7-3.4$ & 57.4 & $6.4-2.3$ & 57.6 \\
\hline PLP-371 & $\mathbf{B}_{2} \mathbf{D}_{6} \mathbf{F}_{\theta}$ & 2 & 29.26 & $5.0-3.5$ & 57.4 & $3.8-2.2$ & 40.7 \\
\hline EC-33866 & $\mathrm{B}_{4} \mathrm{D}_{4} \mathrm{E}_{4} \mathrm{~F}_{2}$ & 4 & 37.83 & $5.4-4.0$ & 60.6 & $4.9-1.6$ & 40.0 \\
\hline Bonneville & $\mathrm{B}_{2} \mathrm{C}_{4} \mathrm{D}_{4} \mathrm{E}_{4}$ & 6 & 31.81 & $5.4-3.9$ & 62.8 & $4.2-2.0$ & 39.5 \\
\hline PLP-401 & $\mathrm{A}_{4} \mathrm{D}_{0} \mathrm{~F}_{4}$ & 4 & 29.21 & $5.2-3.6$ & 64.4 & $4.0-2.3$ & 44.7 \\
\hline $\mathrm{J}-1$ & $\mathrm{~A}_{2} \mathrm{D}_{8} \mathrm{E}_{4}$ & 2 & 30.61 & $6.3-2.9$ & 64.5 & $8.3-2.7$ & 75.6 \\
\hline Arkel & $A_{2} D_{8} E_{4}$ & 2 & 31.96 & $5.6-3.6$ & 65.7 & $8.0-3.1$ & 81.3 \\
\hline PLP-525 & $\mathrm{A}_{4} \mathrm{D}_{4} \mathrm{E}_{\mathrm{B}}$ & 4 & 31.42 & $5.4-4.5$ & 68.8 & $3.2-2.3$ & 40.1 \\
\hline IC-775 & $\mathbf{A}_{2} \mathrm{D}_{8} \mathbf{E}_{4}$ & 2 & 32.11 & 5.54 .5 & 70.8 & $3.5-1.7$ & 38.9 \\
\hline
\end{tabular}



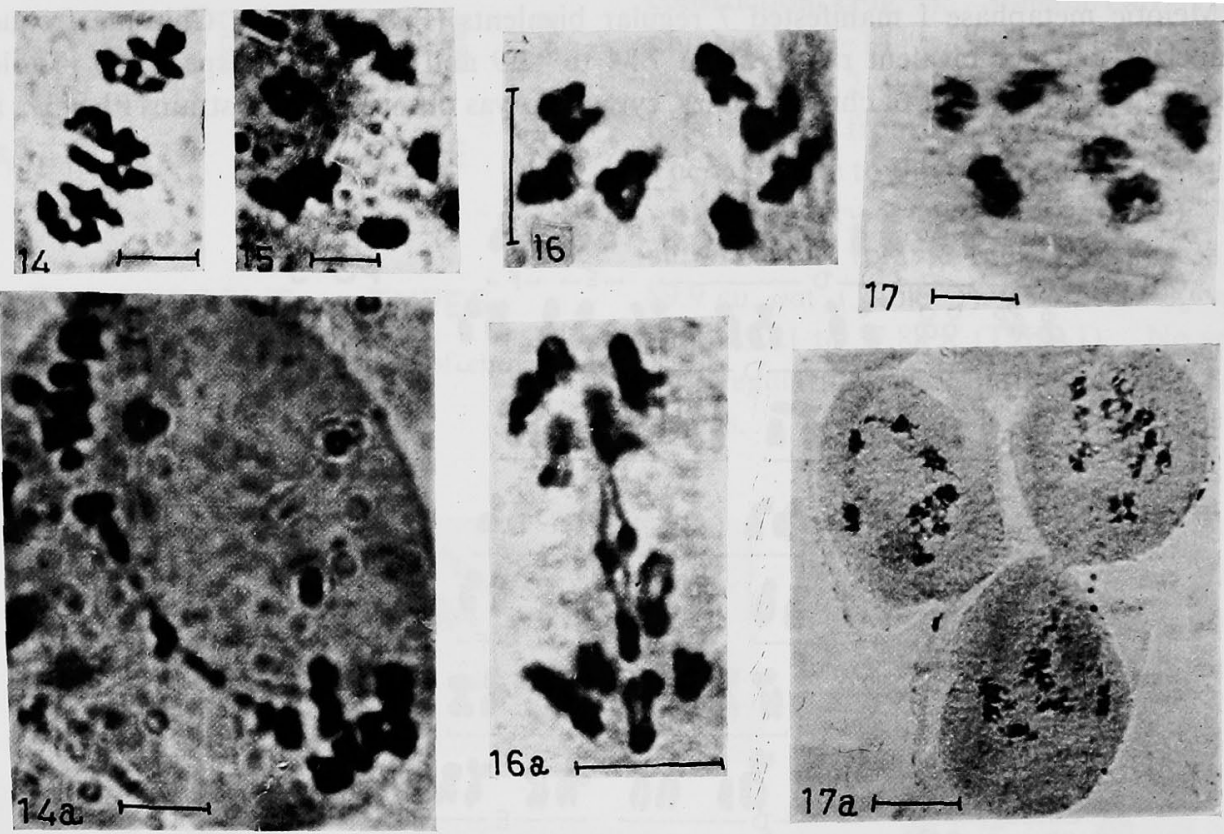

17

162
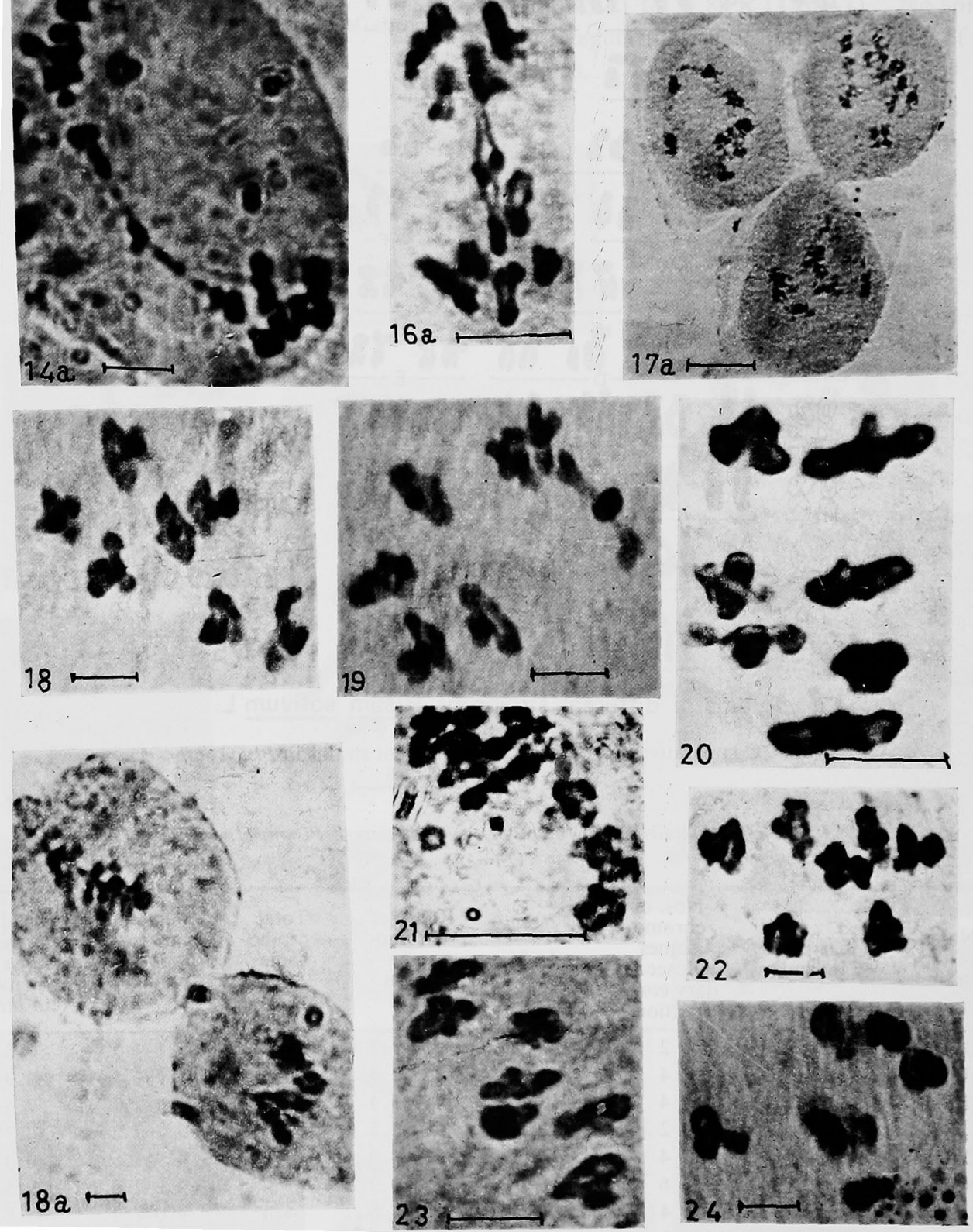

Figs. 14-24. Meiotic metaphase I plates of Pisum sativum L. showing 7 bivalents, cytomixis, sticky chromatin connection and late separation of bivalents. 14, 14a, PG-3. 15, T-163. 16, 16a, B-12. 17, 17a, PLP-371. 18, 18a, EC-33886. 19, Bonneville. 20, PLP-401. 21, J-1. 22, Arkel. 23, PLP-525. 24, IC-775. Bar $=10 \mu \mathrm{m}$. 
17a) and EC-33866 (Fig. 18a) and sticky chromatin connection in anaphase I in PG-3 (Fig. 14a), and B-22 (Fig. 16a).

Discussion

\section{Chromosome characteristics}

Karyotype analysis in 11 strains of Pisum sativum shows gross uniformity in morphology. Somatic chromosome number, $2 n=14$ is constant for all the strains which agrees with earlier reports (Darlington and Janaki Ammal 1945, Yarnell 1962, Sharma and Chatterjee 1963, Sen and Tiwari 1966, Fauzdar and Tandem 1976, Sharma and Gupta 1982).

Chromosomes are mostly long to medium in length with secondary constrictions in one to three pairs. 5 of the 11 strains possess a single pair of chromosomes with secondary constrictions or satellites. Another 5 of the strains show 2 pairs of such chromosomes while in a single strain, Bonneville 3 pairs of chromosomes with secondary constrictions are present (Fig. 13). Previous

Table 2. Details of chromosome behaviour in eleven strains of Pisum sativum L.

\begin{tabular}{lcccl}
\hline $\begin{array}{l}\text { Strains of } \\
\text { Pisum sativum }\end{array}$ & $\begin{array}{c}\text { No. of } \\
\text { bivalents }\end{array}$ & $\begin{array}{c}\text { Chiasma } \\
\text { frequency per } \\
\text { nucleus }\end{array}$ & $\begin{array}{c}\text { Chiasma } \\
\text { frequency per } \\
\text { bivalent }\end{array}$ & $\begin{array}{c}\text { Meiotic } \\
\text { irregularities }\end{array}$ \\
\hline PG-3 & 7 & 10.6 & 1.51 & $\begin{array}{l}\text { Sitcky chromatin } \\
\text { connection in } \\
\text { anaphase I }\end{array}$ \\
T-163 & 7 & 9.5 & 1.35 & Late separation of \\
B-22 & 7 & 12.9 & 1.88 & $\begin{array}{l}\text { bivalent at } \\
\text { anaphase I }\end{array}$ \\
PLP-371 & 7 & 11.3 & 1.61 & $\begin{array}{l}\text { Cytomixis during } \\
\text { prophase I }\end{array}$ \\
EC-33866 & 7 & 11.6 & 1.65 & $\begin{array}{l}\text { Cytomixis during } \\
\text { metaphase I }\end{array}$ \\
Bonneville & 7 & 19.2 & 2.70 & \\
PLP-401 & 7 & 8.4 & 1.20 & \\
J-1 & 7 & 7.91 & 1.13 & \\
Arkel & 7 & 11.0 & 1.57 & \\
PLP-525 & 7 & 7.84 & 1.12 & \\
IC-775 & 7 & 9.1 & 1.30 & \\
\hline
\end{tabular}

reports record either a single pair of chromosomes with secondary constrictions (Sen and Tiwari 1966, Sharma and Gupta 1982) or 2 pairs of such chromosomes (Morrison and Lin 1955, Gopinath and Subramaniam 1963). Primary constrictions in chromosomes range from median to submedian, showing gross morphological similarities in this taxa despite the evolution of different strains. On this basis the homogeneity of the species is undoubtedly clear.

Notwithstanding this overall homogeneity, the detailed karyotype analysis reveals minute differences. Each strain is characterised by its own karyotype, which may serve as one of the identifying criteria. Therefore, based on this parameter, the strain Bonneville can be distinguished from the rest of the strains by the presence of 3 pairs of chromosomes, $\mathrm{B}_{2}$ and $\mathrm{C}_{4}$ with secondary constrictions and 2 pairs of chromosome each $\mathrm{D}_{4}$ and $\mathrm{E}_{4}$ with primary constrictions (Fig. 13). The strain B-22 can also be identified from the rest of the strains by the presence of four pairs of chromosomes $F_{8}$ with nearly median constrictions besides $A_{2}$ and $B_{2}$ types of chromosomes with secondary constrictions. The strains J-1, Arkel and IC-775, unlike the rest have similar karyotype formula of $\mathrm{A}_{2} \mathrm{D}_{8} \mathrm{E}_{4}$, though IC-775 strain can be distinguished from the 
two by its very low total chromosome volume and the strain $\mathrm{J}-1$ by its wide range of chromosome length (Table 1). As these data have been found constant in all the replicate preparations, the validity of the observations is ensured. This is an evidence to show that minute structural alterations have taken place in evolution of different strains of Pisum sativum leading to their diversification.

\section{Total chromosome length and its range}

Despite minor karyotypic differences, absolute chromosome lengths do not show marked variation, excepting certain strains like PLP-525 and IC-775 where the total chromosome lengths are very high, 68.8 and $70.8 \mu \mathrm{m}$ respectively, yet the ranges of their chromosome lengths within the complement are not very wide, 5.4 to $4.5 \mu \mathrm{m}$ and 5.5 to $4.5 \mu \mathrm{m}$, respectively. Maximum variation in the range of chromosome length within a complement has been observed in the strain $\mathrm{J}-1$, where the longest $(6.3 \mu \mathrm{m})$ as well as the shortest $(2.9 \mu \mathrm{m})$ chromosome pairs are present together, while their total chromosome length is quite close to the other strains. The presence of such unusually long or short chromosomes may be due to differential spiralization. Such differences in the range of chromosome size can be explained on the basis of structural alterations which have been adapted for the strains and are more or less universal for this genus (Sutton 1937, Sen and Tiwari 1966).

\section{Total chromosome volume and its range}

As compared to total chromosome length, absolute chromosome volume shows a wide difference. The lowest chromosome volume, $38.9 \mathrm{cu} . \mu \mathrm{m}$ is found in the strain IC-775, though its total chromosome length is the highest among the strains. In sharp contrast, the strain T-163 shows the maximum total chromosome volume, $89.9 \mathrm{cu} . \mu \mathrm{m}$, despite its low absolute chromosome length (Table 1). These differences have been consistently noted, indicating distinct genetic control. The volume of a chromosome is dependent on DNA and protein components as well. The extent to which these components differ as noted in several species (Jensen 1958, Sau et al. 1980, Sharma and Mukhopadhyay 1984, Mukherjee and Sharma 1984, 1986) in the organs tested, is yet to be worked out.

All these features of the chromosome morphology clearly indicate that in the karyotype, the parameters tested to a great extent serve as identifying characters for the different strains of the species. These evidences also indicate the role of structural alterations of chromosomes in the evolution of the strains (vide Sharma and Sharma 1959). The genetic control of these parameters is quite evident.

\section{Chromosome behaviousr}

Meiotic studies, however, reveal regular 7 bivalents in metaphase I. Anaphasic separation too is regular as also observed earlier by Cooper (1938). Chiasma frequency per nucleus and per bivalent shows little variation, ranging from $12.9-7.84$ and $1.88-1.12$ respectively. Irregularities in meiotic behaviour are low in this species. Besides cytomixis, during prophase and metaphase I in the strains PLP-371 and EC-33866 respectively, sticky chromatin connection in anaphase I in PG-3 and late separation of bivalents in B-22, no other irregularities were found. The importance of the irregularities in stable cultivated strains is yet to be ascertained. Earlier workers (Richardson 1929, Håkansson and Levan 1942, Morrison and Lin 1955, Gopinath and Subramaniam 1964, Gottschalk and Pietrini 1965, Gottschalk 1970, Gottschalk and Milutinovic 1970, Klein 1971, Klášterská and Ramel 1981, Medina and Risuno 1981) have observed meiotic irregularities like ring-chromosomes, extra-chromosomal connections and multiple nucleolar formation in Pisum sativum. 


\section{Conclusion}

The discrepant data on chromosome behaviour may be due to varietal differences as well as manifestations of climatic or other conditions. Karytoype has revealed the importance of structural alterations in the evolution of different strains. Meiotic analysis does not reveal any distinct manifestation of structural hybridity in these strains. The formation of clear bivalents may imply that the individuals represent homozygosity for structural alterations in the chromosomes, the heterozygosity being eliminated in the course of evolution. Since the species is a widely cultivated crop, judicious selection has evidently resulted in this homozygosity, playing a very important role in stabilization of these structural alterations.

\section{Summary}

Karyotype analysis of 11 strains of Pisum sativum L. shows gross uniformity in morphology. Somatic chromosome number, $2 \mathrm{n}=14$, is constant for all the strains. Chromosomes are long to medium in length. Primary constrictions range from median to submedian. Secondary constrictions are present in 1 to 3 pairs of chromosomes. Each strain is characterised by its own karyotype, which may serve as an identifying criterion. Absoute chromosome length does not show marked variation, whereas absolute chromosome volume reveals a wide difference. Meiotic analysis discloses regular seven bivalents with a low frequency of irregularities. Karyotype data have revealed the importance of structural alterations in the evolution of different strains. Meiotic behaviour does not reveal any distinct manifestation of structural hybridity in these strains which has been suggested as due to the attainment of homozygosity for structural alterations through selection.

\section{Acknowledgement}

The financial assistance from the University Grants Commission and the Indian National Science Academy are thankfully acknowledged.

\section{References}

Cooper, G. 1938. Cytological investigations of Pisum sativum. Bot. Gaz. 99(3): 584-591.

Darlington, C. D. and Janaki Ammal, E. K. 1945. Chromosome Atlas of Cultivated Plants. London. M/s George Allen and Unwin Ltd.

Fauzdar, A. and Tandem, S. L. 1976. Cytogenetical evolution in Pisum. Cytologia 41(1): 91-104.

Gopinath, P. M. and Subramaniam, M. K. 1963. Persisting nucleoli and micronuclei in the mitotic cells of Pisum sativum Linn. Curr. Sci. 32(4): 169-171.

- and Subramaniam, S. R. 2964. Peculiar chromosomal groupings in the meristematic and polysomatic cells of Pisum sativum L. Caryologia 17(2): 465-470.

Gottschalk, W. 1970. Chromosomes and nuclear migration during microsporogenesis of Pisum sativum. Nucleus 13(1): 1-9.

- and Milutinovic, M. 1970. Die Analyse hochgradiger Chromosomenverkettungen in der Meiosis von Pisum sativum. Caryologia 23(4): 473-488.

- and Pietrini, R. V. 1965. The influence of mutant genes on chiasmata formation. Cytologia 30(1): 88-97.

Håkansson, A. and Levan, A. 1942. Nucleolar conditions in Pisum. Hereditas 28(3,4): 436-440.

Jensen, W. A. 1958. The nucleic acid and protein content of root tip cells of Vicia faba and Allium cepa. Exp. Cell Res. 14(3): 575-583.

Klášterská, I. and Ramel, C. 1981. Peculiarities in PMC meiosis of Pisum sativum. Theor. Appl. Genet. 59(4): 297-302.

Klein, H. D. 1971. Eine Pisum Mutante mit zahlreichen meiotischen Störungen. Cytologia 36(1): 15-25.

Medina, F. J. and Risuno, M. D. C. 1981 . Nucleolar structure and dynamics during meiotic prophase in pea (Pisum sativum) ovules. Biol. Cell 42(213): 79-86. 
Morrison, J. W. and Lin, Shu-Chang 1955. Chromosomes and nucleoli in Pisum sativum. Nature 175(4451): 343-344.

Mukherjee, S. and Sharma, A. K. 1984, Varietal constancy in the amount of DNA in the roots of Pisum sativum L. In Perspectives in Cytology and Genetics 4: 51-54.

- and - 1986. Intervarietal relationships between chromosome size, nuclear DNA amount and protein content in Cajanus cajan (L.) Millsp. In Perspectives in Cytology and Genetics 5: 735-740.

Richardson, E. 1929. A chromosome ring in Pisum. Nature 124(3128): 578-579.

Sau, H., Sharma, A. K. and Choudhuri, R. K. 1980. DNA, RNA and protein content of isolated nuclei from different plant organs. Indian J. Exp. Biol. 18(12): 1519-1523.

Sen, S. K. and Tiwari, C. B. 1966. A comparative karyotypic study of five varieties of pea. Nucleus $9(2)$ : $173-176$.

Sharma, A. K. and Chatterjee, T. 1963. Radiation study as a means of working out the strain difference of Pisum sativum L. Folia Biol. 11(2): 159-166.

- and Mukhopadhyay, Sandip 1984. Feulgen microspectrophotometric estimation of nuclear DNA of species and varieties of three different genera of Marantaceae. Proc. Indian Acad. Sci. 93(3): 337-347. - and Sharma, A. 1959. Chromosomal alterations in relation to speciation. Bot. Rev. 25(3): 514-544.

Sharma, P. C. and Gupta, P. K. 1982. Karyotypes in some pulse crops. Nucleus 25(3): 81-85.

Sutton, E. 1937. Cytological studies in Pisum I. Structural hybridity in P. humuli. Ann. Bot. 1(4): 785-795.

Yarnell, S. H. 1962. Cytogenetics of vegetable crops. Bot. Rev. 28(4): 465-537. 